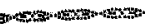

Note

(5)

(Received April 25, 1989)

\section{IN VIVO BLOOD COMPATIBILITY OF REGENERATED SILK FIBROIN}

\author{
By Hiroshi Sakabe ${ }^{* 1}$, Hiraku Ito*2, Takeaki Miyamoto*2, \\ Yasuharu Noishiki*3 and Wan Shik Ha*4 \\ *1 (Faculty of Textile Science, Kyoto Institute of Technology, Matsugasaki, \\ Sakyo, Kyoto 606) \\ *2 (Institute for Chemical Research, Kyoto University, Uji. Kyoto 611.) \\ * 3 (Department of surgery, Okayama University, Misasa, Tottori 682.02) \\ *4 (Department of Textile Engineering, College of Engineering. Seoul \\ National University, San 56-1. Shinlim-dong, Kwanak-gu, Seoul 151. \\ Korea)
}

\begin{abstract}
Blood compatibility of regenerated silk fibroin was examined by in vivo blood tests. In vivo tests were made by a method of peripheral vein indwelling suture. The coating of sample fibroin on the polyester suture was made by casting either from aqueous or from formic acid solution. The fibroin-coated sutures from aqueous solution were treated with methanolic aqueous solution in order to denature the silk fibroin, and implanted into a jugular and femoral vein of a dog. The results of the test method employed in this work indicate that the regenerated silk fibroin is nonthrombogenic.
\end{abstract}

\section{INTRODUCTION}

Silk is a unique natural fiber produced by an animal. the larva of Bombyx mori. The silk filament is composed of two proteins; fibroin and sericin. The former is the main component of silk filaments and is one of the representative structural proteins. The latter is the silk gum that acts as cement to hold the filaments together. The sequence of silk fibroin having a molecular weight of about 300,000 consists mainly of Gly-Ala-Gly-Ala-Gly-X, where $X$ is alanine or serine ${ }^{1)}$.

Silk fibroin can be solubilized without chemical modification, and regenerated into fibers and films ${ }^{2.3)}$ : It is also characteristic of silk fibroin that the higher-order structure as well as surface characteristics of the fibers and films can be varied by thermal, mechanical and che mical denaturation. It is of interest to examine the characteristics of regenerated silk fibroin as a biomaterial. Several attempts have been made to use the unique biochemical properties of fibroin proteins in biomedical field ${ }^{4.5)}$. However, no study has been reported on the blood compatibility of these proteins.
In this paper, the results on in vivo experiments for blood compatibility of regenerated fibroin are described.

\section{EXPERIMENTAL}

\subsection{Materials}

Raw silk fibers of Bombyx mori were degummed twice with $0.3 \%$ sodium oleate aqueous solution for $2 \mathrm{~h}$ at $95^{\circ} \mathrm{C}$ and washed with boiling water. After rinsing with deionized water, the fibers were dried in vacuo at $50^{\circ} \mathrm{C}$. All the chemicals were of highest purity available and used without further purification.

\subsection{Sample preparation}

The $10 \%(\mathrm{w} / \mathrm{v})$ silk fibroin solution was prepared by dissolving the degummed silk fibroin in a ternary solvent system of calcium chloride/ethanol/water ( $1 / 2 / 8$ mole ratio) at $70^{\circ} \mathrm{C}$. The solution was then dialyzed against deionized water using a Visking cellulose tube and clarified by centrifugating it at $12,000 \mathrm{rpm}$ for $30 \mathrm{~min}$. The diluted aqueous solution was concentrated up to the $5 \%$ solute concentration by drying with an electric fan and subjected to further sample preparation.

Since the sample films prepared by casting from 
aqueous solutions thus obtained were soluble in water, they were treated with organic solvents to make waterinsoluble ${ }^{3)}$. Methanol treatment was carried out at $25^{\circ} \mathrm{C}$ using a $50 \%$ methanolic aqueous solution. The number attached to the sample code indicates the treating time in minutes. A film, coded FA, was prepared by casting a ca. $5 \%$ formic acid solution of the sample fibroin onto a Teflon plate. The details of the preparation of these films have been described elsewhere ${ }^{3)}$.

\subsection{Infrared spectra}

IR spectra were obtained with a JASCO model A-102 Spectrophotometer. The sample films were prepared by casting as described above, and then treated with methanol while holding between two rectangular acryl frames.

\subsection{In vivo test for blood compatibility}

The in vivo test for blood comaptibility was performed according to a method of peripheral vein indwelling multifilament developed by one of the authors (Y.N. $)^{6-8)}$. The specimen was prepared as follows: A polyester suture No. 1-0 (USP) of $10 \mathrm{~cm}$ in length was coated with a sample fibroin. The sample fibroin was coated on polyester sutures by casting either from an aqueous solution or from a formic acid solution. The samples prepared from a aqueous solution were treated with a $50 \mathrm{wt} \%$ methanolic aqueous solution at $25^{\circ} \mathrm{C}$ for a desired time. Polymercoated sutures were washed thoroughly with deionized water and stored in a sterilized physiological solution at room temperature.

In the animal experiments (in this work, dog), an 18 gauge needle was inserted into the peripheral vein (jugular and femoral vein) under general anesthesia. The suture was introduced through the needle into the lumen of the vessel. After the needle was withdrawn, the edge of the suture was ligated to the connective tissue near the puncture site of the vessel. After an adequate time, the dog was sacrificed by acute exsanguination from the aorta under general anesthesia with the administration of heparin $(2-3 \mathrm{mg} / \mathrm{kg})$. The vein in which the suture had been inserted was opened gently and suture was examined visually.

\section{RESULTS AND DISCUSSION}

\subsection{Structural Characteristics of Regenerated Fibroin Films}

Fig. 1 show the IR spectra of the silk fibroin films treated with $50 \%$ methanolic aqueous solution, together

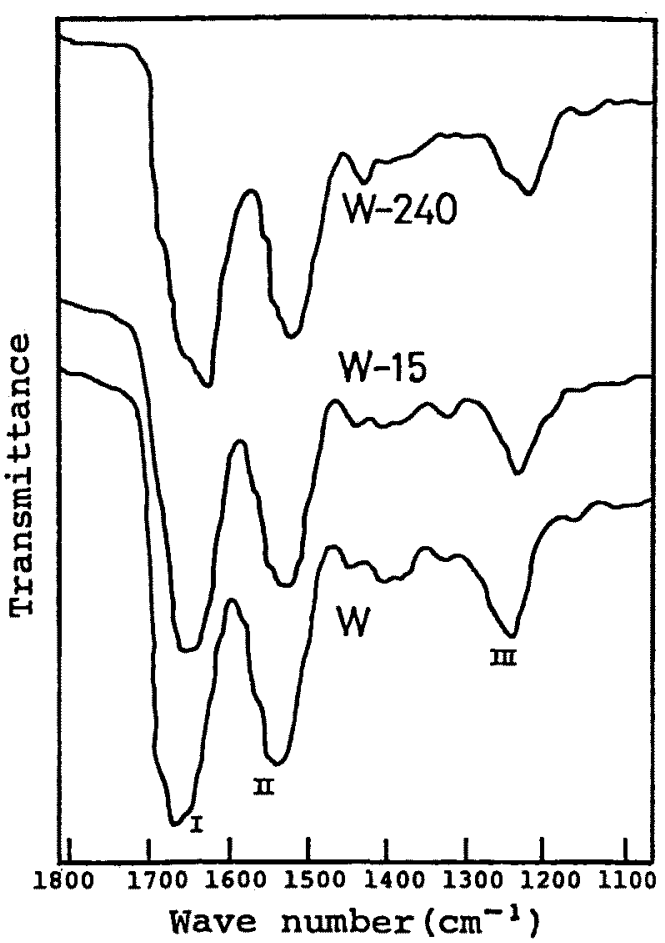

Fig. 1 IR spectra of denatured silk fibroin films.

with that of untreated film. Amides I, II, and III band, the characteristic infrared bands of proteins, are overlapped and yield three or four peaks which may be assigned to the random coil, $\alpha$-helix, and $\beta$-pleated sheet conformations of silk fibroin molecular chains ${ }^{9,10)}$. Detailed analy. ses of these spectra revealed that the treatment with aqueous solution of organic solvents such as methanol or formic acid caused the conformational transformation from random coil to $\beta$-pleated sheet, while $\alpha$-helix remains unchanged ${ }^{3)}$, indicating the denaturation of the silk fibroin into water-insoluble structure.

To estimate the crystallinity of the sample films, an in-

Table 1 IR crystallinity indices of denatured silk fibroin films

\begin{tabular}{lccc}
\hline $\begin{array}{c}\text { Sample } \\
\text { code }\end{array}$ & $\begin{array}{c}\text { casting } \\
\text { solvent }\end{array}$ & $\begin{array}{c}\text { R crystallinity } \\
\text { index, U }\end{array}$ & Remarks \\
\hline W & water & 0.57 & $\begin{array}{c}\text { untreated } \\
\text { W-15 }\end{array}$ " \\
W-240 & 0.60 & $\begin{array}{c}\text { treated with methanol } \\
\text { for } 15 \text { min } \\
\text { treated with methanol } \\
\text { for } 240 \text { min }\end{array}$ \\
FA & formic acid & 0.72 & untreated \\
\hline
\end{tabular}


frared index proposed by Bhat et al. ${ }^{10)}$ was used. This index is given by

$$
\mathrm{U}=\frac{\mathrm{I}_{1.265}}{\mathrm{I}_{1.235}}
$$

where Is are the optical densities at 1.265 and $1.235 \mathrm{~cm}^{-1}$, which are assigned to amide III band due to $\beta$-sheet and random coil conformation, respectively. The results are given in Table 1 . It can be seen that the IR crystallinity index increases as the treating time increases.

\subsection{Blood Compatibility}

The results on the blood compatibility of regenerated silk fibroin samples are shown in Table 2. The symbols

Table 2 In vivo blood compatibility of denatured silk fibroin films.

\begin{tabular}{lcc}
\hline \multirow{2}{*}{ Sample code } & \multicolumn{2}{c}{ Thrombus formation $^{\mathrm{a})}$} \\
\cline { 2 - 3 } & \multicolumn{2}{c}{ Implantation period } \\
& 1 day & 14day \\
\hline W-15 & - & - \\
W-240 & - & - \\
FA & - & $\pm \sim+$ \\
Polyester & + + & $+1+$ \\
\hline
\end{tabular}

a) See text for symbols

used to evaluate the results have following significance: The + symbol indicates the relative degree of thrombus formation along the entire length of the coated surface. The - symbol denotes the case where no thrombus formation had occurred. According to the criteria of the test method employed in this work, the regenerated silk fibroin samples examined here exhibited an excellent blood compatibility except for FA sample. FA sample was found to be thrombogenic after implantation for 2 weeks. However, it may be considered that this result was due not to the nature of the sample but to the damage of the walls of the blood vessel by the movement of the sample film. FA film was very hard as compared with other sample films.

Fig. 2a shows a macroscopic view of a suture with generated silk fibroin. No thrombus is observed around the suture (S). For comparison, the result on the film of wool keratin derivative, which was evaluated as ++ , is shown in Fig. $2 b$.

Lee-White method, in which the coagulation time of whole blood is measured, is the most widely employed in

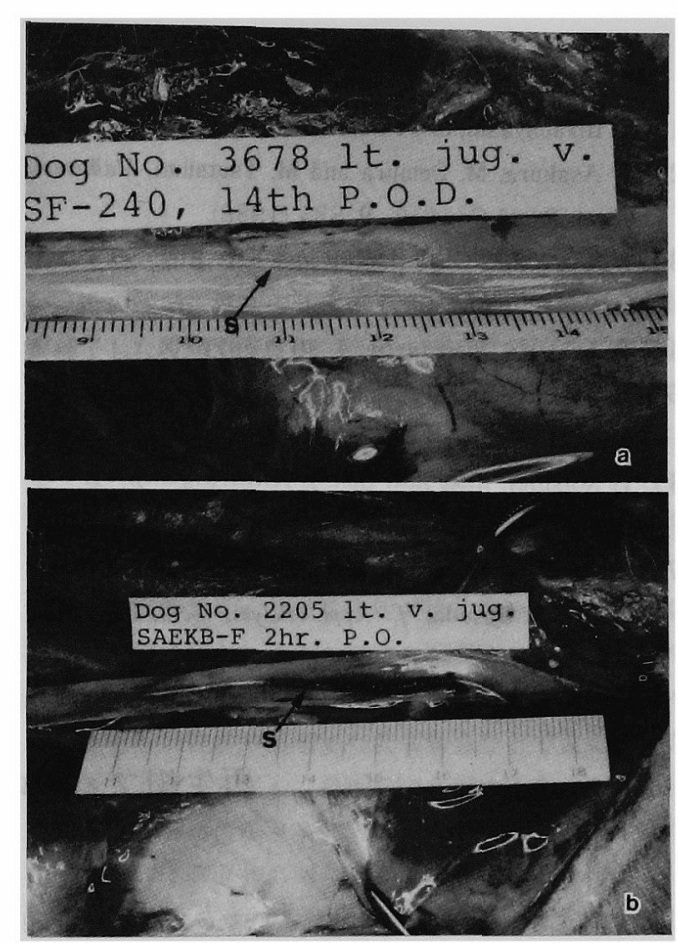

Fig. 2 Macroscopic views of polyester sutures coated with regenerated silk fibroin (a) and wool keratin derivative (b) after implatation in the femoral vein of dog for 14 days and $2 \mathrm{~h}$, respectively. (a) No thrombus was observed around the su. ture (S); (b) in this case, the blood compatibility was evaluated as ++ .

vitro test method for evaluating the blood compatibility of polymeric materials ${ }^{7)}$. Recently $\mathrm{Ha}$ et al. ${ }^{11)}$ also found that by the criteria of this test method, regenerated silk fibroin has an excellent blood compatibility. The IR results are in good agreement with those obtained here.

Silk fibroin is a biopolymer produced by the larva of Bombyx mori and an amphiphilic polymer. It is not surprizing that such a silk fibroin exhibits an excellent blood compatibility without chemical modification ${ }^{12)}$. However, to elucidate the chracteristics of these structural proteins as biomaterial, its tissue biocompatibility shoud be also examined ${ }^{13)}$. Such a study is in progress in our laboratory.

This work was presented at the Annual Meeting of the Society of Fiber Science and Technology, Japan, held in Tokyo in June, 1988. 


\section{REFERENCES}

1) K. Hirabayashi, Sen-i Gakkaishi, 40, 119 (1984).

2) T. Asakura, M. Demura and M. Tsutsumi, Makromol. Chem. Rapid Commun., 9, 835 (1988).

3) W.S. Ha, S.K. Oh, J.H. Kim and K.Y. Kim, Sen-i Gakkaishi, 43, 587 (1987).

4) T. Asakura, Bioindustry, 4, 36 (1987).

5) M. Demura and T. Asakura, Biotechnol. Bioeng., 33. 598 (1989).

6) Y. Noishiki, Jinko.Zoki (Jm. J. Artif. Organs), 11, 794 (1982).

7) H. Ito, T. Miyamoto, H. Inagaki, Y. Noishiki, H. Iwata and T. Matsuda, J. Appl. Polym. Sci., 32, 3413 (1986).
8) T. Miyamoto, S. Takahashi, S. Tsuji, H. Ito, H. Inagaki and Y. Noishiki, J. Appl. Polym. Sci.. 31, 2303 (1986).

9) T. Miyazawa and E. R. Blout, J. Am. Chem.Soc., 83, 712 (1961).

10) N.V. Bhat an S.M. Ahirrao. J. Polym. Sci. Polym. Chem. Ed., 21, 1273 (1983).

11) W.S. Ha, unpublished results.

12) T. Miyamoto, H. Ito, S. Takahashi, O. Hasegawa, H. Inagaki and Y. Noishiki, Sen-i Gakkai Symposia Preprints (1987). 1B15; S. Takanashi, Ph.D. Dissertation. Kyoto University, 1988.

13) T. Miyamoto, S. Takahashi, H. Ito, H. Inagaki and $Y$, Noishiki, J. Biomed. Mater. Res., 23, 125 (1989).

\section{再生絹フィブロインの血液適合性 \\ 京都工芸織維大学緎維学部 坂部 寛 京都大学化学研究所伊藤 啓 宮本武明 \\ 岡山大学医学部野一色泰晴 \\ ソウル大学校工科大学 河 完植}

タンパク質変性剤水溶液で可溶化した兴, 再生した変 性縝フィブロインの抗血栓性を成犬を用いた in vivoの 動物実験により険討した。変性による試料の非水溶性化 処理はメタノールおよびギ酸を用いて行い, 抗血栓性は
ポリエステルマルチフィラメントに被覆した試料を成犬 の静腺内に留置する方法で評価した。静脈内留置 2 週間 後の結果より，変性綟フィブロインは抗血栓性を有する ことがわかった。 